\title{
Price for the Allocation of Railway Infrastructure Capacity as a Tool for the Improvement of Train Transport Planning
}

\author{
Jaromir Šroký ${ }^{1, *}$ \\ ${ }^{1}$ University of Pardubice, Faculty of Transport Engineering, 53210 Pardubice, Czech Republic
}

\begin{abstract}
The introducing of legal background for capacity allocation in the Czech Republic. Author analysis of price for capacity allocation in the Czech Republic and in Europe. The proposal of the capacity allocation price which should lead the Railway undertaking's path request to the suitable product. The author summarizes the legislative background of the railway infrastructure capacity allocation, and then compared the levying of charges for the allocation of railway infrastructure capacity in the Czech Republic as well as in the neighbouring states - Germany, Poland, Austria and Slovakia.
\end{abstract}

\section{Introduction}

Economic development has a bearing on an increased transport demand. Large amounts of goods need to be transferred from producers to consumers, which require quality transport services. Along with the increasing transport demand, there is a growing supply of carriers on the transport market. It is crucial for the state to adopt certain regulatory actions in order to preserve market equilibrium and protect the market. Issuing of licences and certificates to carriers is one of these regulatory actions; the allocation of railway infrastructure capacity is another one. In view of the geographical, demographic, economic and urbanistic make-up of Europe, most states depend on the import and export of their products and goods. Uniform conditions of network access and the provision of facilities and services need to be set for the opening transport markets. The uniform conditions for the EU member states are approved and made public by the European Parliament and the Council in their regulations and directives. A regulation enters into force and becomes legally applicable in all member states just as it was approved and made public. Directives need to be implemented in the legislation of individual member states. Directive 2001/14/EC of the European Parliament and of the Council of 26th February 2001 considers the allocation of railway infrastructure capacity, the levying of charges for the use of railway infrastructure and the issuing of safety certification. This directive was amended by the Directive 2012/34/EU of the European Parliament and of the Council of 21st November 2012 establishing a single European railway area.

*Corresponding author: jaromir.siroky@upce.cz 


\section{The legislative background of the allocation of railway infrastructure capacity}

In the Czech Republic, the conditions for the allocation of railway infrastructure capacity are defined by Act No. 266/1994 coll. on railways, which governs the relationships between the railway infrastructure capacity allocation body (railway manager) and the carrier. The process of railway infrastructure capacity allocation must be non-discriminatory for all carriers who meet the conditions for access to railway infrastructure. Správa železniční dopravní cesty (hereinafter only referred to as „SŽDC“) is the railway infrastructure capacity allocation body for the national railway and the state-owned regional railways [1].

Upon the accession of the Czech Republic to the European Union (EU) on 1st May 2004, the need arose to adapt the legislation of the Czech Republic. Act No. 103/2004 Coll. of 11 th February 2004 amending Act No. 266/1994 Coll. on railways, as amended, came into force [2].

The amendment to the Act No. 266/1994 Coll. implemented the Directive 2001/14/EC of the European Parliament and of the Council of 26th February 2001 on the allocation of railway infrastructure capacity and the levying of charges for the use of railway infrastructure and safety certification.

In 2012, the Directive 2001/14/EC was amended by the Directive 2012/34/EU of the European Parliament and of the Council of 21st November 2012 establishing a single European railway area [3].

The Directive 2012/34/EU† of the European Parliament and of the Council states that the EU member states must ensure that the schemes for levying charges for the use of railway infrastructure and for the allocation of railway infrastructure capacity are governed by the principles given in the Directive 2012/34/EU [3] and make it possible for the infrastructure managers to trade the available infrastructure capacity and ensure its optimal effective use. The Directive 2012/34/EU [3] defines the content of the minimum access package, it defines what belongs to the railway access to equipment and services, it defines which services belong among basic services and which are provided as ancillary services. These services must be provided by all the railway managers in the EU to all the carriers meeting the conditions of access to the railway network.

The allocation of railway infrastructure capacity in the Czech Republic is a part of the minimum range of services in compliance with the Decree No. 76/2017 Coll. on the content and scope of services provided to the carrier by the railway manager and by the service facility manager. The railway to be used for the train run represents another part of the minimum scope of services provided, i.e. ensuring the railway operation (operation management) and ensuring the operability of the railway (maintenance and repairs of the infrastructure).

For railway lines where SŽDC is the railway infrastructure capacity allocation body, the calculation of the price for the allocation of railway infrastructure capacity depends on:

- The duration of the period from the submission of the application and the allocation of railway infrastructure capacity and the requested first day of its drawing,

- The relationship of the submitted application for the allocation of railway infrastructure capacity and the term of the establishing of the annual working timetable or its planned changes,

- The processing difficulty of the application.

For railway lines where SŽDC is the railway infrastructure capacity allocation body, the price for the use of a railway for a train run depends on:

\footnotetext{
${ }^{\dagger}$ Directive 2012/34/EU of the European Parliament and of the Council of $21^{\text {st }}$ November 2012 establishing a single European railway area
} 
- The length and parameters of the railway in question,

- Type of transport (passenger, freight),

- The parameters of the train and on the type of price applied - basic price, promotion price, increased price.

Each railway infrastructure capacity allocation body shall draw up their rail network statement and make it public no later than 12 months before the beginning of effectiveness of the working timetable in a way which enables remote access. The network statement shall set non-discriminatory rules for the allocation and withdrawing of railway infrastructure capacity, for access to the railway, for its use and for the calculation of the price for this use [2].

\section{The analysis of the system setting the process for the allocation of railway infrastructure capacity in the Czech Republic and neighbouring states}

In this chapter, the author shall deal with the charging scheme for the allocation of railway infrastructure capacity and the charging scheme for the use of railway infrastructure in the Czech Republic and in the neighbouring states, i.e. in Germany, Poland, Austria and Slovakia. Charges are levied on the minimum access package; some states levy a charge on it. Some states levy charges on it by parts, such as the Czech Republic, which levies charges for the allocation of railway infrastructure capacity and charges for the use of railway infrastructure separately.

The idea of calculating a single charge for the use of the railway infrastructure in the whole EU originated as early as in 2003 as the PARTNER project (Path Allocation Reengineering of Timetable Networks for European Railways), which was opened on 1st October 2003. Currently, the project is no longer taking place. It has been replaced by project Christine.

Each railway manager from any EU country issues their Network Statement which must have a unified structure so that it's easier to understand for the applicants, The Network Statement must contain basic information, such as conditions of access to the railway network, the description of infrastructure, the description of the process of application and allocation of the railway infrastructure capacity, dispute resolution in case of insufficient railway infrastructure capacity, services provided to the applicants and carriers (minimum access package and railway line access to facilities and services for carriers), the price for the use of the railway and for the services provided. So far, a unified charging scheme has not been implemented on the European network due to various legal and legislative reasons on the part of the member states. The carriers would agree with the unified charging mechanism, as it would substantially simplify the reporting of their performances and services used and their recording. Furthermore, all the charges would be unified and the carrier would be able to calculate the price of transit through all the states in advance.

As part of their minimum access packages, the individual railway managers define the content of the minimum access package and which services the carriers are entitled to and how they are broken down.

In the Czech Republic, there are several railway infrastructure capacity allocation bodies. The levying of charges, which is subject to price regulation in the Czech Republic, is a part of the process of allocation of railway infrastructure capacity. The levying of charges depends on the length of the railway in question and the total amount of eligible costs of the allocation of the railway infrastructure capacity [4].

The railway managers and railway infrastructure capacity allocation bodies charge the applicants for the use of the national and regional railway infrastructure: 
1. The prices including the economically substantiated costs directly incurred on the operation of railway transport, i.e. the following:

- The price of the capacity allocation body for allocating the railway infrastructure capacity,

- The price of the railway manager for the use of the railway for the train run,

- The price of the railway manager for ensuring railway network access of carriers to service facilities

2. Prices for additional services.

The minimum scope of services provided by the railway manager to the entitled carriers are laid down by Decree No. 76/2017 Coll. on the content and scope of services provided to the carrier by the railway manager and by the service facility manager.

Prices for regulated services stated in paragraph 1) are subject to rectification as per the effective assessment of the Ministry of Finance, which is made public in the Official price bulletin of the Ministry of Finance - „The use of state and regional railway infrastructure“.

The table (Table No.1) summarizes the charging for the allocation of capacity by the individual capacity allocation bodies in the Czech Republic.

Table 1. The Charging for the allocation of railway infrastructure capacity in the Czech Republic.

Source: Source: author, based on [5-12]

\begin{tabular}{|l|l|l|l|}
\hline $\begin{array}{l}\text { Railway infrastructure } \\
\text { capacity allocation body }\end{array}$ & \multicolumn{2}{|l|}{ Charging for the allocation of railway infrastructure capacity } \\
\hline AŽD Praha & \multicolumn{2}{|l|}{} & NO \\
\hline Czech railways & & NO \\
\hline $\begin{array}{l}\text { Jindřichohradecké místní } \\
\text { dráhy }\end{array}$ & YES & $\begin{array}{l}\text { For the train path / per day / different rates for } \\
\text { regional timetable and ad hoc }\end{array}$ & NO \\
\hline $\begin{array}{l}\text { Moravian-Silesian } \\
\text { Region }\end{array}$ & YES & For the train path / per day / progressive rates & \\
\hline KŽC & ANO & $\begin{array}{l}\text { For the train path / per day / per km of planned } \\
\text { path / different rates for regional timetable and } \\
\text { ad hoc }\end{array}$ & \\
\hline $\begin{array}{l}\text { Inter-municipal } \\
\text { cooperative of the Desná } \\
\text { valley }\end{array}$ & SŽDC & & \\
\hline
\end{tabular}

The SŽDC, a member of RNE, is the most significant railway infrastructure capacity allocation body.

The maximum timespan of the allocated railway infrastructure capacity is $20 \mathrm{hrs}$ (the period from the departure from the first point of the network until the arrival to the last point in the network of SŽDC). For railway lines belonging to the European Rail Network for Competitive Freight (ERNCF) as per the Regulation 913/2010/EU, the capacity may also be allocated by the Corridor-OSS (C-OSS) on behalf of SŽDC. The conditions and procedures for the allocation of railway infrastructure capacity by C-OSS are made public for the individual corridors in the Corridor Information Document (CID) [13].

The company DB Netz AG (railway manager in Germany), a member of RNE (Rail Net Europe), is the most significant railway manager in Germany. The same applies to the company PKP Polskie Linie Kolejowe (PKP PLK) in Poland (railway manager in Poland),

${ }^{\ddagger}$ Regulation 913/2010/EU of $22^{\text {nd }}$ September 2010 concerning a European rail network for competitive freight (ERNCF) 
to the company ÖBB-Infrastruktur AG in Austria (railway manager in Austria) and to the company Železnice Slovenskej republiky (ŽSR) in Slovakia (railway manager in Slovakia).

The Table (Tab. No. 2) summarizes the levying of charges in the given states and shows the differences in charging. Only basic parameters are given. For example, the parameter of the environmental impact of the traction unit applied by ÖBB-Infrastruktur AG isn't considered. The parameter considering the use of the tilt body applied by DB Netz AG isn't considered either [14].

The most similar model of charging for the railway infrastructure to the one used by SŽDC is the model used by ŽSR, where charges are also levied according to actual parameters of trains (also considered by ÖBB-Infrastruktur AG), considering the type of railway, the weight of the train and an independent traction unit on electrified railway lines. To the contrary, neither the speed of the train, nor the railway lines with overloaded infrastructure ae considered. Furthermore, SŽDC uses a different price for passenger and freight transport as opposed to ŽSR.

DB Netz Ag and PKP PLK levy charges according to the planned train parameters. The type of railway is considered by all the stated railway managers. DB Netze, PKP PLK and ŽSR do not have a different price for passenger and freight transport. The rate according to the weight of the train is applied by PKP PLK (gradually), by ŽSR and by ÖBBInfrastruktur $\mathrm{AG}$ for freight transport. DB Netz AG has a single rate for freight of up to $3000 \mathrm{t}[15]$.

An independent traction unit on electrified railways isn't considered by DB Netz AG, PKP PLK and for the passenger transport for ÖBB-Infrastruktur AG (they do take it into account for freight transport). Apart from ŽSR, the consumption of traction energy isn't considered by DB Netz AG, PKP PLK, ÖBB-Infrastruktur AG. The speed of the train is considered by DB Netz AG, where there is a surcharge for slow trains (under $50 \mathrm{~km} / \mathrm{h}$ ) on high-speed tracks and by ÖBB-Infrastruktur AG, where there is a surcharge for trains with a speed of more than $160 \mathrm{~km} / \mathrm{h}$. Railways with overloaded infrastructure are considered by DB Netz AG and ÖBB-Infrastruktur AG.

Table 2. Comparison of charges levied for the infrastructure in the Czech Republic and neighbouring states. Source: author, based on [5, 13-21]

\begin{tabular}{|c|c|c|c|c|c|c|c|c|}
\hline & $\begin{array}{l}\text { Payments as } \\
\text { per planned } \\
\text { or preal } \\
\text { parameters }\end{array}$ & $\begin{array}{l}\text { The type of } \\
\text { railway } \\
\text { considered. }\end{array}$ & $\begin{array}{l}\text { Different } \\
\text { prices for } \\
\text { passenger } \\
\text { and freight } \\
\text { transport }\end{array}$ & $\begin{array}{l}\text { The weight } \\
\text { of the train } \\
\text { considered }\end{array}$ & $\begin{array}{l}\text { Independent } \\
\text { traction unit on } \\
\text { an electrified } \\
\text { railway } \\
\text { considered }\end{array}$ & $\begin{array}{l}\text { Traction } \\
\text { energy } \\
\text { consumption } \\
\text { considered }\end{array}$ & $\begin{array}{l}\text { The speed of } \\
\text { the train } \\
\text { considered }\end{array}$ & $\begin{array}{l}\text { Railways with } \\
\text { overloaded } \\
\text { infrastructure } \\
\text { considered }\end{array}$ \\
\hline SŽDC & real & yes & yes & $\begin{array}{l}\text { Gross tonne- } \\
\text { kilometres }\end{array}$ & yes & no & no & no \\
\hline PLK & planned & yes & no & $\begin{array}{l}\text { Rate per train } \\
\mathrm{km} \text { by weight }\end{array}$ & no & no & no & no \\
\hline ŽSR & real & yes & no & $\begin{array}{l}\text { Gross tonne- } \\
\text { kilometres }\end{array}$ & yes & yes & no & no \\
\hline
\end{tabular}




\section{Conclusion}

In each part of the present contribution, the author summarised the legislative background of the railway infrastructure capacity allocation, then compared the levying of charges for the allocation of railway infrastructure capacity in the Czech Republic as well as in the neighbouring states - Germany, Poland, Austria and Slovakia. It follows from the comparison that the price for the allocation of the railway infrastructure capacity is accounted for and charged independently only by SŽDC. The railway managers of the neighbouring infrastructures, such as DB Netze AG, PKP PLK, ÖBB-Infrastruktur AG or ŽSR, do not charge for the allocation of the railway infrastructure capacity independently, but they include it in the minimum access package. However, all these cooperating railway managers apply sanctions or reservation charges for the cancellation of the allocated capacity of the railway infrastructure or for the failure to use it as a regulatory measure.

This paper is supported by the research project "From horse-drawn railway to intermodal transport" within Visegrad Fund.

\section{References}

1. J. Široký, et al., Transport Technology and Control (Tribun EU: Brno, Czech Republic, 2014)

2. Act No. 266/1994 coll. on railways (2016)

3. Directive 2012/34/EU of the European Parliament and of the Council (2012)

4. H. Saláková, Monitoring of economic factors by allocation of railway infrastructure capacity (University of Pardubice, Czech Republic, 2015)

5. Railway Infrastructure Administration. Statement on national and regional railway, Available online: http://www.szdc.cz (2017)

6. SŽDC, The Network Statement on nationwide and regional rail networks (2017)

7. SŽDC, The Network Statement on regional rail networks, (AŽD Prague, Czech Republic, 2017), Available online: http://www.azd.cz/admin/files/Dokumenty/pdf/Kompletni-zneni-Prohlaseni-o-draze2017-Cizkovice-Obrnice-Kopidlno-Dolni-Bousov.pdf

8. The Network Statement on nationwide and regional rail networks of the Czech railways (2017)

9. The Network Statement on regional rail networks Jindřichohradecké mistni dráhy, Available online: http://docplayer.cz/1333471-Prohlaseni-o-draze-regionalni.html (2016)

10. The Network Statement on regional rail networks Moravskoslezský kraj, Available online: http://www.msk.cz/assets/doprava/prohlaseniodraze_2017.pdf (2016)

11. KŽC, The Network Statement on regional rail networks, Available online: http://www.kzc.cz/muzejni-zeleznice-senovka/ prohlaseni-o-draze (2016)

12. The Network Statement on rail Inter-municipal cooperative of the Desná valley, Available online: http://www.sart.cz/wp-content/uploads/Prohlasení-o-drazeaktualizace-2016.pdf (2016)

13. Regulation 913/2010/EU of concerning a European rail network for competitive freight (ERNCF) (2010) 
14. DB NETZE, Network Statement, Available online: http://fahrweg.dbnetze.com/fahrwegen/network_access/network_statement/2017.html (2016)

15. S. Bahri, Y. Huseyin, U. Yasin, A. Guneri, G. Bahadir, E. Turan, The Scientific World Journal 2014 (2014), DOI: 10.1155/2014/630320

16. PKP PLK, Network Statement, Available online: http://en.plk_sa.pl/files/public/user_upload/pdf/Reg_przydzielania_tras/Regulamin_20 16_2017/Network_Statement_2016-2017_v11.pdf(2016)

17. ÖBB Infrastruktur AG, Network Statement, Available online: http://www.oebb.at/infrastruktur/en/Network_Access//NetworkStatement/2017.jsp (2016)

18. ÖBB Infrastruktur AG, Product_Catalogue_2017_Train_Path.pdf, Available online: http://www.oebb.at/infrastruktur/en/Network_Access/Product_Train_Path.jsp (2016)

19. Li, Rui, R. Roberto, Journal of Construction Engineering and Management 143, 6 (2017)

20. T. Dollevoet, D. Huisman, L. Kroon et al., Computers \& Operations Research 143, 203-217 (2017)

21. N. Stojadinovic, B. Boskovic, M. Bugarinovic, Transport Means - 20th International Scientific Conference on Transport Means Location, 735-740 (Juodkrante, Lithuania, 2016) 